\title{
Repression of engrailed 2 inhibits the proliferation and invasion of human bladder cancer in vitro and in vivo
}

\author{
YUNFEI LI ${ }^{1 *}$, HAITAO LIU ${ }^{2 *}$, CAIYONG LAI ${ }^{1}$, ZEXUAN SU $^{1}$, BAOLI HENG $^{1}$ and SHUANGQUAN GAO 3 \\ ${ }^{1}$ Department of Urology, The First Affiliated Hospital, Jinan University, Guangzhou, Guangdong 510630; \\ ${ }^{2}$ Department of Obstetrics and Gynecology, Guangdong Women and Children's Hospital, Guangzhou, Guangdong 511400; \\ ${ }^{3}$ Department of Pathology, Yuebei People's Hospital, Shaoguan, Guangdong 512026, P.R. China
}

Received November 25, 2014; Accepted February 27, 2015

DOI: $10.3892 /$ or.2015.3858

\begin{abstract}
Engrailed 2 (EN2) is a member of the homeobox gene family. Many studies suggest that overexpression of EN2 protein may be associated with tumor development, including bladder cancer (BC). However, to date, the mechanisms of how EN2 functions to promote BC progression remain elusive. The present study introduced RNAi to silence the expression of $\mathrm{EN} 2$ in $\mathrm{BC}$ cell lines. In vitro invasion and migration assays and in vivo experiments were carried out to examine the functions of EN2 in BC invasion and metastasis. The results of the present study indicated that EN2 was significantly expressed in BC cells. Ectopic expression of EN2 in normal urothelial cells significantly enhanced cellular proliferation and invasion, but inhibited cellular apoptosis. EN2 knockdown significantly promoted cell cycle arrest and apoptosis of BC cells with inhibition of proliferation and invasion in vitro as well as EN2 knockdown decreased the tumor growth of BC. The tumor growth was decreased by regulation of the cell cycle, apoptosis and epithelial-mesenchymal transition-related proteins, with inhibition of metastasis to the liver and lung in vivo. Furthermore, EN2 knockdown significantly decreased the levels of pAkt-473, pAkt-308 and phosphatidylinositol 3-kinase (PI3K), whereas EN2 knockdown increased the expression of PTEN in vitro. Taken together, EN2 may be a candidate oncogene in $\mathrm{BC}$ by activating the PI3K/Akt pathway and inhibiting PTEN, and may be a potential therapeutic target for the treatment of $\mathrm{BC}$.
\end{abstract}

Correspondence to: Professor Zexuan Su, Department of Urology, The First Affiliated Hospital, Jinan University, Huangpu Avenue West 601, Guangzhou, Guangdong 510630, P.R. China

E-mail: suz2008@126.com

*Contributed equally

Key words: EN2, bladder cancer, RNAi, PI3K/Akt pathway, therapeutic target

\section{Introduction}

Bladder cancer (BC) is the fourth most common cancer in men worldwide, with an estimated 70,530 new cases and a projected number of 14,680 deaths in the United States in 2010 (1). In China, $\mathrm{BC}$ is the eighth most common cancer among all malignant tumors and the most common cancer of the genitourinary system in men (2). At initial diagnosis, $70-75 \%$ of the patients are afflicted with non-muscle invasive bladder cancer (NMIBC), in which the papillary tumor invades the urothelium (Ta) and lamina propria (T1), or carcinoma in situ (CIS), with a relatively flat tumor within the urothelium, while the remaining 25-30\% already have a muscle invasive bladder cancer (MIBC) $(3,4)$. More than $90 \%$ of BC cases belongs to the pathological type, transitional cell (urothelial) carcinomas (TCCs), and 3-7\% are squamous cell carcinomas; adenocarcinoma is rare and accounts for $<2 \%$ of all BC cases (5). The majority of TCCs present as papillary NMIBC; however, $~ 80 \%$ of patients with NMIBC suffer from recurrence within 1 year to 2 years and $\sim 8 \%$ will progress to MIBC although standard treatment is performed, including transurethral resection and adjuvant intravesical chemotherapy or immunotherapy (3). Patients with MIBC are treated by radical cystectomy (3). Despite the radical cystectomy and systemic therapy, 50\% of patients with invasive tumors die from metastasis (6). Recent progress has been made in diagnosis and treatment, but the molecular mechanisms underlying the development and progression of BC remain poorly understood and MIBC prognosis is still unsatisfactory (7). Further investigation of the molecular mechanisms of development and progression of $\mathrm{BC}$ is necessary to develop new methods for the treatment of BC.

Engrailed (EN) is a member of the homeobox gene family and was first characterized in Drosophila. The encoded homeodomain-containing transcription factor has important functions in development and has been identified in annelids (8), mollusks (9), insects (10), echinoderms, chordates (11) and vertebrates (12). In vertebrates, two engrailed (EN) genes have been discovered, namely, EN1 and EN2, which differ slightly in their specific functions $(13,14)$. High levels of both EN1 and EN2 are expressed in alar (dorsal) cells of the midbrain/hindbrain border region during brain development and affect the survival of mesencephalic dopaminergic neurons $(15,16)$. The EN2 gene has also been implicated in 
Table I. The synthesized siRNA sequences for construction of plasmids for knockdown of human EN2 expression.

\begin{tabular}{ll} 
siRNAs & \multicolumn{1}{c}{ Sequences (5'-3') } \\
\hline siRNA-1 & $\begin{array}{l}\text { Sense: GATCCCGGCTCAAGGCCGAGTTCCATTCAAGAGATGGAACTCGGCCTTGAGCCTTTTTT } \\
\text { Antisense: CTAGAAAAAAGGCTCAAGGCCGAGTTCCATCTCTTGAATGGAACTCGGCCTTGAGCCCGG }\end{array}$ \\
siRNA-2 & Sense: GATCCCGGGTCTACTGTACGCGCTATTCAAGAGATAGCGCGTACAGTAGACCCTTTTT \\
& Antisense: CTAGAAAAAAGGGTCTACTGTACGCGCTATCTCTTGAATAGCGCGTACAGTAGACCCCGG \\
siRNA-3 & Sense: GATCCCCAAAGAAGAAGAACCCGAATTCAAGAGATTCGGGTTCTTCTTCTTTGTTTTT \\
& Antisense: CTAGAAAAAACAAAGAAGAAGAACCCGAATCTCTTGAATTCGGGTTCTTCTTCTTTGCGG
\end{tabular}

early muscle development, with expression in the murine mandibular arch, particularly myoblasts, which give rise to the masseter, temporalis, and lateral and medial pterygoid muscles involved in jaw closure (17). Germline mutations in EN may have profound effects on embryological development.

Evidence suggests that overexpression of EN2 protein may be associated with tumor development in adult humans, particularly in breast (18), prostate (19-21) and ovarian cancers (22). A recent study indicated that EN2 is expressed in and secreted by $\mathrm{BC}$ cell lines and patient tumor specimens, justifying an evaluation of urinary EN2 as a diagnostic biomarker in $\mathrm{BC}$ using archived samples from an established biospecimen collection. Moreover, high expression of EN2 is associated with the pathological grade and stage of BC (23). However, the mechanisms of how EN2 functions to promote $\mathrm{BC}$ progression remain elusive. Given the significance of EN2 in cancer tumorigenesis, EN2 is hypothesized to have critical functions in $\mathrm{BC}$ tumorigenesis and metastasis. In the present study, the effects of EN2 knockdown on the proliferation, apoptosis, and invasion of $\mathrm{BC}$ were investigated in vitro and in vivo using small interference RNA (siRNA) for EN2. The obtained results suggest that downregulation of EN2 may be effective in the inhibition of tumor growth and progression of $\mathrm{BC}$.

\section{Materials and methods}

Cell lines and cell culture. T24, RT4 and EJ human BC cell lines as well as normal uroepithelial SV-HUC-1 cells were obtained from the American Type Culture Collection (ATCC; Manassas, VA, USA). Normal human bladder epithelial cells (NHBECs) were purchased from PriCells Co., Ltd. (Wuhan, China). The cells were thawed and cultured at $37^{\circ} \mathrm{C}$ in $5 \% \mathrm{CO}_{2}$ in Dulbecco's modified Eagle's medium (DMEM; HyClone, Logan, UT, USA) containing 10\% fetal bovine serum (FBS), $2 \mathrm{mmol} / 1$ glutamine, $1 \mathrm{mmol} / 1$ sodium pyruvate, $10 \mathrm{mmol} / 1$ 4-(2-hydroxyethyl)-1-piperazineethanesulfonic acid, $100 \mathrm{U} / \mathrm{ml}$ penicillin $\mathrm{G}, 100 \mathrm{mg} / \mathrm{ml}$ streptomycin and $50 \mathrm{ng} / \mathrm{ml} \mathrm{SDF-1}$ (Sigma, St. Louis, MO, USA).

Construction of recombinant plasmids. A pair of primers with double restriction enzyme cutting sites (EcoRI-forward primer, 5'-CCGGAATTCATGGAGGAGAATGACCCCAAGCCT GGCG-3' and BamHI-reverse primer, 5'-CCGCTCGAGCT ACTCGCTGTCCGACTTGCCCTCCTTG-3') was designed to amplify the full-length cDNA of EN2 (GenBank Accession
No.NM_001427) from the cellular cDNA library of the human bladder epithelium. The restriction enzymes EcoRI and Bam HI were then used to cut the PCR products and expression vector pcDNA3.1 (Invitrogen). Finally, the EN2 Flag-tagged overexpression vector was obtained through ligation reaction. In addition, the accurate sequence of EN2 open reading frame was confirmed by DNA sequencing.

Construction of the plasmids for knockdown of human EN2 expression. The following three siRNAs were designed based on the EN2 sequence: siRNA 1, 5'-GGCTCAAGGCCGAGT TCCA-3', siRNA 2, 5'-GGGTCTACTGTACGCGCTA-3', and siRNA 3, 5'-CAAAGAAGAAGAACCCGAA-3'. Oligonucleotides with a sequence predicted to induce efficient RNAi of EN2 (containing sense and antisense sequences) were synthesized by Sigma (Shanghai, China). The synthesized sequences are shown in Table I. The oligonucleotides were annealed in sodium chloride-Tris-EDTA buffer at $94^{\circ} \mathrm{C}$ for $5 \mathrm{~min}$ and cooled gradually. The double-stranded products were cloned downstream to the human U6 promoter of the pGCsilencer U6/Neo/GFP (pGC) plasmid (Shanghai Genechem Co., Ltd., Shanghai, China). The products were designated as EN2-siRNA1, EN2-siRNA2 and EN2-siRNA3. A scramble sequence (5'-TTCTCCGAACGTGTCACGT-3') without significant homology to any mammalian gene sequence was inserted into the pGC plasmid and used as a negative control siRNA.

Cell transfection. Cells were plated on 6-well plates at 80-90\% confluency (recombinant plasmid transfection) or 30-50\% confluency (siRNA transfection). All cell transfections were implemented using Lipofectamine 2000 (Invitrogen) according to the manufacturer's protocol. An empty vector was used as a negative control. To determine whether the recombinant plasmids were transduced into the tumor cells, the green fluorescent protein (GFP) expression of EJ cells in the NC-siRNA, EN2-siRNA1, EN2-siRNA2 and EN2-siRNA3 groups was assessed using an inverted fluorescence microscope at 24, 48 and $72 \mathrm{~h}$ after transduction, respectively. Ten fields were randomly selected, and the delivery efficiency was counted as follows: number of positive cells/total number of cells x $100 \%$ under the same field. The samples were considered positive regardless of the degree of brightness.

Selection of stable transfected cell clones. NHBECs transfected with pcDNA3.1 and pcDNA3.1+EN2 as well as BC 
Table II. Primary antibodies for western blot analysis.

\begin{tabular}{lcll}
\hline Primary antibodies & Manufacturer & Product no. & Dilutions \\
\hline EN2 & Abcam & ab28731 & $1: 20000$ \\
Cyclin D1 & Abcam & ab16663 & $1: 200$ \\
E-cadherin & Abcam & ab40772 & $1: 20000$ \\
TP53 & Abcam & ab65021 & $1: 500$ \\
PTEN & Abcam & ab32199 & $1: 500$ \\
VEG & Abcam & ab46154 & $1: 1000$ \\
PDGF & Abcam & ab125268 & $1: 800$ \\
Bcl-2 & Abcam & ab59348 & $1: 1000$ \\
BAX & Abcam & ab69643 & $1: 1000$ \\
MMP-2 & Abcam & ab92536 & $1: 1000$ \\
MMP-9 & Abcam & ab38898 & $1: 1000$ \\
p-Akt (Ser 473) & Santa Cruz & sc-33437 & $1: 500$ \\
p-Akt (Thr 308) & Santa Cruz & sc-135650 & $1: 500$ \\
PI3K p110 & Santa Cruz & sc-7189 & $1: 500$ \\
PI3K p85 & Santa Cruz & sc-292114 & $1: 500$ \\
GAPDH & Abcam & ab9385 & $1: 5000$ \\
\hline
\end{tabular}

cells transfected with pGCsilencer plasmids were cultured in the medium with added G418 (Gibco) for 2 weeks. Stable transfected clones were selected using G418. Briefly, two EJ clones stably expressing EN2 siRNA (siRNA1) (named as $\mathrm{C} 1$ and $\mathrm{C} 2$, respectively) and one EJ clone stably expressing NC-siRNA (named as NC) were identified using indirect immunofluorescent assay, which were further verified with qRT-PCR and western blot analysis.

Quantitative $R T-P C R$. Total RNA was isolated from frozen tumor tissue or $1 \times 10^{6}$ cells using the TRIzol reagent (Invitrogen). Total RNA was subsequently reverse transcribed to cDNA using M-MLV reverse transcriptase (Promega) according to the manufacturer's instructions. DNase (Promega) was used to completely eliminate DNA contamination in the total RNA before reverse transcription. qRT-PCR was performed using the SYBR-Green qPCR SuperMix kit (Invitrogen) in the ABI PRISM ${ }^{\circledR} 7500$ Sequence Detection system (Applied Biosystems, Foster City, CA, USA). Specific primers were: EN2, F-5'-TCTTGGAGTGGCTGCTTCTG3' and R-5'-TCCTGGAGGATTCTGAGTTCTT3'; 18S rRNA, F-5'CCTGGATACCGCAGCTAGGA3' and R-5'-GCGGCG CAATACGAATGCCCC-3'. Thermal cycle conditions were as follows: $5 \mathrm{~min}$ at $95^{\circ} \mathrm{C}$ and 40 cycles of $1-5 \mathrm{sec}$ at $95^{\circ} \mathrm{C}$, $32 \mathrm{sec}$ at $60^{\circ} \mathrm{C}$, and $30 \mathrm{sec}$ at $72^{\circ} \mathrm{C}$. The comparative threshold cycle method was used to calculate the amplification fold. $18 \mathrm{~S}$ rRNA was employed as a reference control gene to normalize the expression value of the target genes. Triple replicates were performed for each gene, and the average expression value was calculated for subsequent analysis. The relative expression levels of the genes were calculated using the $2^{-\Delta \Delta \mathrm{Ct}}$ method (24).

Western blot analysis. In brief, the cells were rinsed thrice with ice-cold PBS and then lysed in lysis buffer (PBS at $\mathrm{pH} 7.4,1 \%$ Triton $\mathrm{X}-100,10 \mathrm{mM}$ sodium deoxycholate, $3 \mathrm{mM}$ SDS, and $1 \mathrm{mM}$ EDTA with protease inhibitors) at $4^{\circ} \mathrm{C}$ for
$30 \mathrm{~min}$. Protein concentrations were determined using a BCA protein assay (Thermo Fisher Scientific). Equal quantities of protein were subjected to SDS-PAGE and transferred to Immobilon-P transfer membranes (Millipore). Successive incubations with primary antibodies (Table II) and horseradish peroxidase-conjugated secondary antibody were conducted. Immunoreactive proteins were then detected using the enhanced chemiluminescence system (Bio-Rad Laboratories). For the protein in xenograft tissues, the harvested xenograft samples were cut into small pieces and dissolved in lysis solution. The complex solution was homogenized and sonicated for $5 \mathrm{~min}$ on ice. Protein concentrations were determined using a BCA protein assay. All proteins to be validated were separated by SDS-PAGE with $20 \mu \mathrm{g}$ of protein per lane and transferred to Immobilon-P transfer membranes [in transfer buffer (pH 11.0), $25 \mathrm{mmol} / 1$ Tris, $0.2 \mathrm{~mol} / 1$ glycine, $20 \%$ (v/v) methanol] for $45 \mathrm{~min}$ at $1.5 \mathrm{~mA} / \mathrm{cm}^{2}$ on a semidry electroblotter (Bio-Rad Laboratories, Richmond, VA, USA). The membranes were blocked with $1 \%$ skim milk for $1 \mathrm{~h}$ at $25^{\circ} \mathrm{C}$ and probed with the primary antibody (Table II) and then horseradish peroxidase-conjugated secondary antibody. GAPDH was used as an internal control to ensure equal loading. Bands were scanned using a densitometer (GS-700; Bio-Rad Laboratories, Hercules, CA, USA), and relative quantification was performed using Image-Pro Plus 6.0 software (Media Cybernetics Inc., Silver Spring, MD, USA).

Cell cycle assay. Cells $\left(1 \times 10^{6}\right)$ were obtained from appropriate samples, and nuclei were stained with PI. Flow cytometry was performed using FACSCalibur (BD Biosciences, San Jose, CA, USA), and the cell fraction in each cell cycle phase was determined using the cell cycle analysis platform in FlowJo software (Tree Star Inc., Ashland, OR, USA).

Apoptosis assay. Annexin V-FITC/PI apoptosis kit was purchased from Nanjing KeyGen Biotech Co., Ltd. (Nanjing, China). In brief, cells $\left(5 \times 10^{5}\right)$ were collected, washed, resuspended in PBS and Annexin V-FITC (1.25 $\mu \mathrm{l})$ and PI $(10 \mu \mathrm{l})$ were added. The cells were then incubated for $20 \mathrm{~min}$ at $4^{\circ} \mathrm{C}$. Tests were performed in triplicate for each sample, and analyses were performed by FACScan flow cytometry (Becton-Dickinson, San Jose, CA, USA) with FlowJo software according to the manufacturer's guidelines. The TUNEL assay was performed using In Situ Cell Death Detection kit, POD (Roche Applied Science, Basel, Switzerland) according to the manufacturer's protocol. The sections were observed under a bright-field microscope, and the number of apoptotic cells in the tumor tissue in each section was counted in 10 different microscopic fields.

In vitro invasion assay. In brief, a polycarbonate filter was coated with Matrigel (BD Biosciences, Franklin Lakes, NJ, USA) and incubated at $37^{\circ} \mathrm{C}$ for half an hour. The cells were harvested by typsinization and suspended in DMEM serumfree medium with $0.1 \%$ BSA at $5 \times 10^{5}$ cells $/ \mathrm{ml}$. Approximately $100 \mu 1$ of the cell suspensions was placed in the upper chambers, and $600 \mu \mathrm{l}$ of complete medium was filled into the lower chambers. The cells were allowed to invade at $37^{\circ} \mathrm{C}$ in $5 \%$ $\mathrm{CO}_{2}$ for $48 \mathrm{~h}$ and fixed with $4 \%$ formaldehyde for $15 \mathrm{~min}$. The cells on the lower surface of the membranes were stained 
with crystal violet for $10 \mathrm{~min}$. The invaded cells in five fields (i.e., upper, lower, left, right and middle) were counted under a microscope at a x200 magnification. Experiments were repeated at least three times, and data are presented as the number of cells passing through the filters.

Cell proliferation assay. Cell proliferation was assessed using CellTiter $96{ }^{\circledR}$ AQueous One Solution Cell Proliferation assay (MTS assay; Promega) according to the manufacturer's instructions. Cells were plated on 96 -well plates at $1 \times 10^{4}$ cells/well (i.e., $100 \mu \mathrm{l} /$ well) and incubated for 3 days. MTS $(10 \mu \mathrm{l})$ was added to each well after $0,24,48$ and $72 \mathrm{~h}$ of incubation. The cells were incubated at $37^{\circ} \mathrm{C}$ in $5 \% \mathrm{CO}_{2}$ for another $4 \mathrm{~h}$. The value of the optical density was measured at a wavelength of $490 \mathrm{~nm}$ using a microplate reader (multiscan MK3; Thermo Fisher Scientific).

In vivo assay. All animal studies were carried out in accordance with the Guide for the Care and Use of Laboratory Animals published by the US National Institutes of Health. The experimental procedures and protocols were approved by the Ethics Committee for Animal Experiments of Jinan University. In brief, male BALB/c nude mice aged 4 weeks were obtained and maintained in a pathogen-free facility. Cells from two EJ cell clones stably expressing EN2 siRNA ( $\mathrm{C} 1$ and $\mathrm{C} 2)$ and one stable clone expressing a control scramble siRNA (NC) were suspended in PBS at a concentration of $5 \times 10^{6}$ cells $/ \mathrm{ml}$ and injected subcutaneously in the back of the mice $(n=6$ for each group). The tumor size was measured every 7 days, and the tumor volume was determined using the simplified formula of a rotational ellipsoid $\left(\mathrm{L} \mathrm{x} \mathrm{W}^{2} \times 0.5\right)$. Six weeks after inoculation, the mice were sacrificed and dissected for collection of primary tumors and organs, including lungs and livers. The tissues were then fixed in $4 \%$ paraformaldehyde and embedded in paraffin for further study.

Immunohistochemistry. Five-micrometer sections of formalinfixed, paraffin-embedded tissue were cut onto silanized glass slides, deparaffinized in xylene, rehydrated in graded ethanol concentrations (100, 95, 70 and 50\%), and finally submerged in PBS. The sections were blocked for endogenous peroxidase with $3 \%$ hydrogen peroxide solution for $15 \mathrm{~min}$ and placed in an autoclave with $0.01 \mathrm{~mol} / \mathrm{l}$ sodium citrate solution at $121^{\circ} \mathrm{C}$ for $3 \mathrm{~min}$ for antigen retrieval. The sections were incubated with EN2 (1:500) and Ki-67 (Abcam; ab66155, 1:200) primary antibodies overnight at $4^{\circ} \mathrm{C}$ and then incubated with biotinlabeled secondary antibody at room temperature for $1 \mathrm{~h}$. Negative controls were performed by replacing the primary antibody with PBS. Diaminobenzidine tetrahydrochloride was used as a chromogen. All sections were then counterstained with hematoxylin and observed under a bright-field microscope.

Statistical analysis. Quantitative data are expressed as mean \pm SD (standard deviation). The statistical significance of differences between groups was determined by one-way ANOVA analysis. Enumeration of the data was analyzed by Mann-Whitney $\mathrm{U}$ test. $\mathrm{P}<0.05$ was considered to indicate a statistically significant result. All data were analyzed with SPSS 17.0 software.
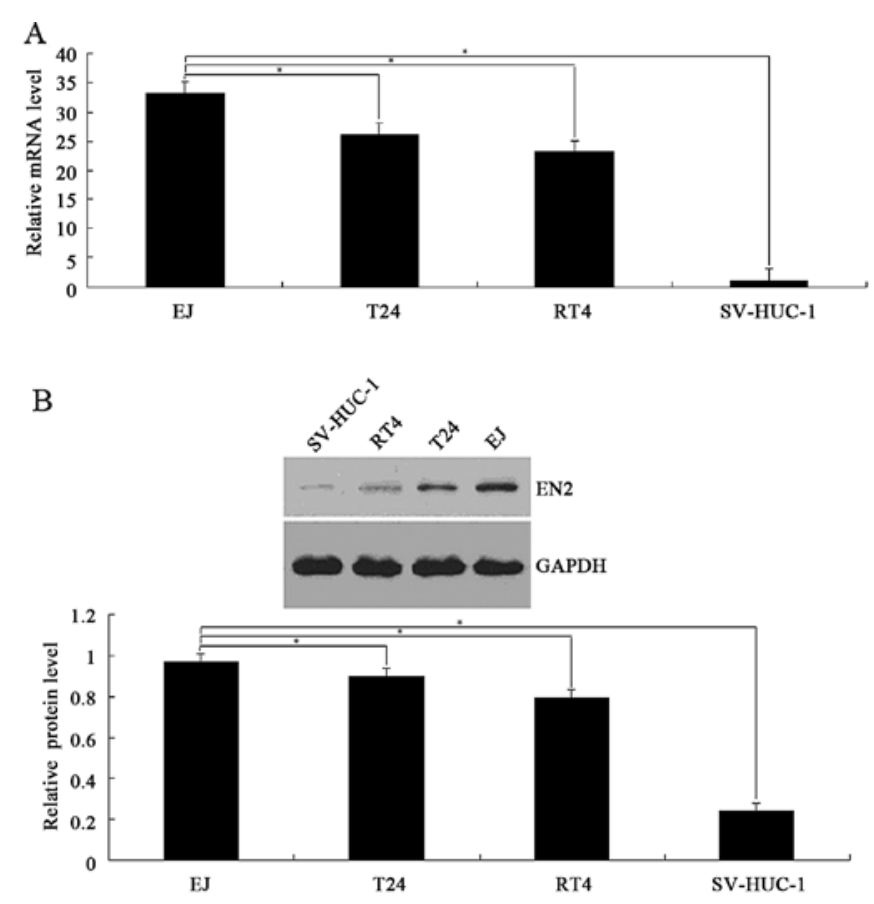

Figure 1. EN2 expression in BC cells. (A) mRNA levels of EN2 were detected by qRT-PCR in T24, RT4 and EJ cell lines as well as in the SV-HUC-1 cell line. mRNA expression of EN2 in the SV-HUC-1 cell line was defined as 1. (B) Protein levels of EN2 were measured using western blot analysis in various cell lines. Results are demonstrated by histograms to quantify the expression levels. Data are presented as mean $\pm \mathrm{SD}$ (error bars). ${ }^{*} \mathrm{P}<0.05$.

\section{Results}

Significant expression of EN2 in BC cells. The EN2 expression was examined using quantitative real-time polymerase chain reaction (qRT-PCR) and western blot analysis in human BC cell lines, including T24, RT4 and EJ cell lines, as well as normal uroepithelium SV-HUC-1 cells. The EN2 mRNA levels were significantly higher in all $\mathrm{BC}$ cell lines than the level in the SV-HUC-1 cells. The EN2 mRNA level in the EJ cell line was also significantly higher than levels in the T24 and RT4 cell lines (Fig. 1A). The EN2 protein levels showed the same trend with mRNA expression (Fig. 1B). Therefore, the EJ cell line was selected for further study.

EN2 overexpression promotes cell proliferation, invasion and apoptosis. To investigate the possible oncogenic function of EN2 in normal bladder epithelial cells, we selected the immortalized and non-transformed bladder epithelial cell line SV-HUC-1 for further study. The stable cells transfected with pcDNA3.1 and pcDNA3.1+EN2 as well as non-transfected cells were examined for the effects of EN2 overexpression on cellular proliferation, invasion and apoptosis. The expression of exogenous EN2 mRNA and protein was verified using qRT-PCR and western blot analysis, respectively (Fig. 2A and B).

The cell growth curve drawn with absorbance at $490 \mathrm{~nm}$ showed that the stable SV-HUC-1 cells transfected with pcDNA3.1+EN2 had larger values of cell viability than the corresponding stable SV-HUC-1 cells transfected with pcDNA3.1 and the non-transfected SV-HUC-1 cells (Fig. 2C). Moreover, SV-HUC-1 cells ectopically expressing EN-2 were more invasive compared with the non-transfected cells 

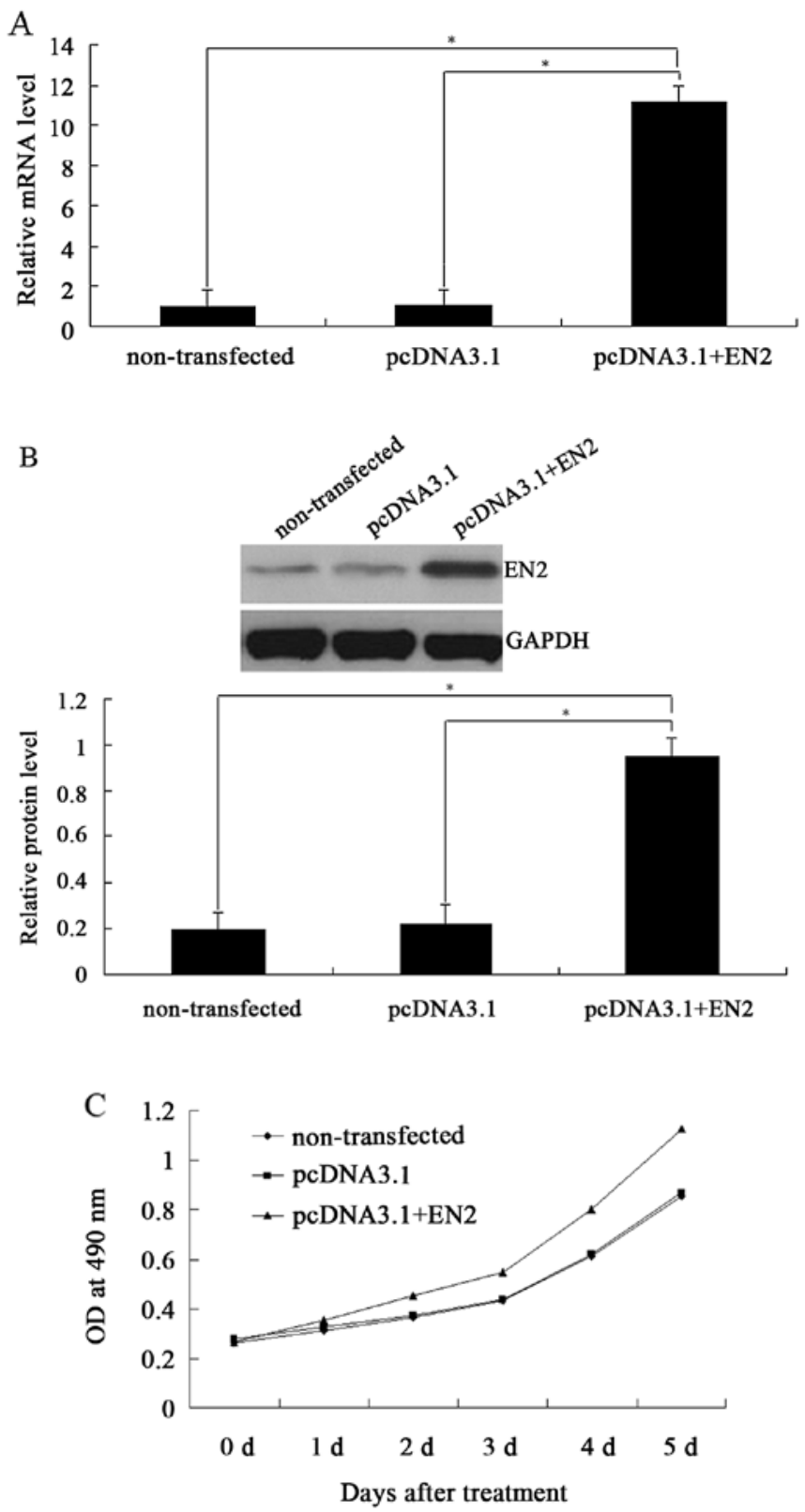

Figure 2. Effects of EN2 overexpression on the cellular proliferation, invasion and apoptosis in SV-HUC-1 cells with different treatments in vitro. (A) mRNA levels of EN2 were detected using qRT-PCR in the SV-HUC-1 cell line with different treatments. (B) Protein levels of EN2 were measured using western blot analysis in the SV-HUC-1 cell line with different treatments. (C) Growth curve after SV-HUC-1 cells were differentially treated. (D) Effects of EN2 overexpression on the invasive ability of the SV-HUC-1 cells with different treatments. (E) Effects of EN2 overexpression on the apoptosis of SV-HUC-1 cells with different treatments; ${ }^{*} \mathrm{P}<0.05$.

or pcDNA3.1-transfected cells (Fig. 2D). Apoptotic analysis with flow cytometry showed a lower proportion of apoptotic SV-HUC-1 cells ectopically expressing EN-2 compared with the non-transfected cells or pcDNA3.1-transfected cells (Fig. 2E). In summary, the results indicated that EN2 overexpression enhanced cellular proliferation and invasion while inhibiting cellular apoptosis.

Effects of EN2 siRNA on the expression of EN2 in EJ cells in vitro. The delivery efficiency of NC-siRNA, EN2-siRNA1,
D
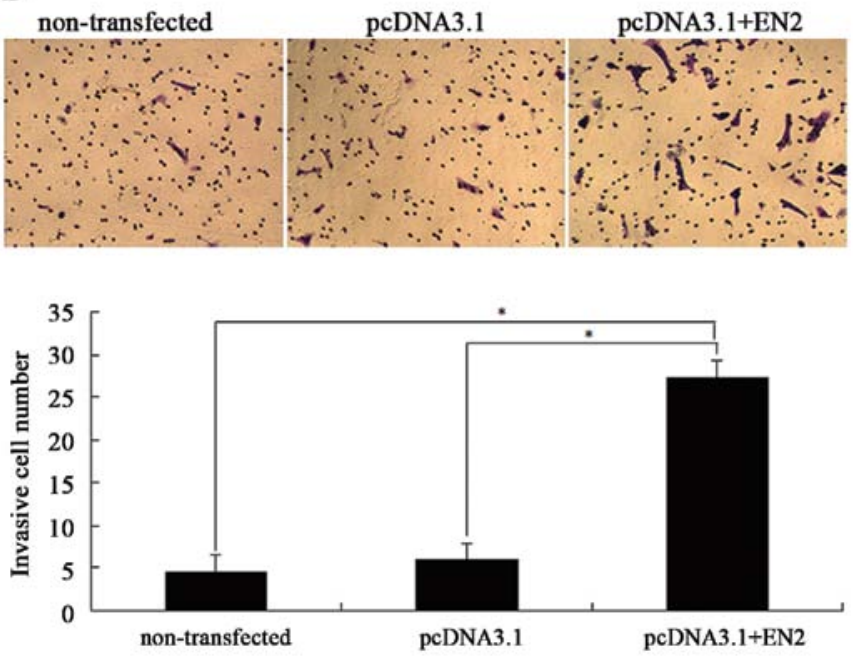

E
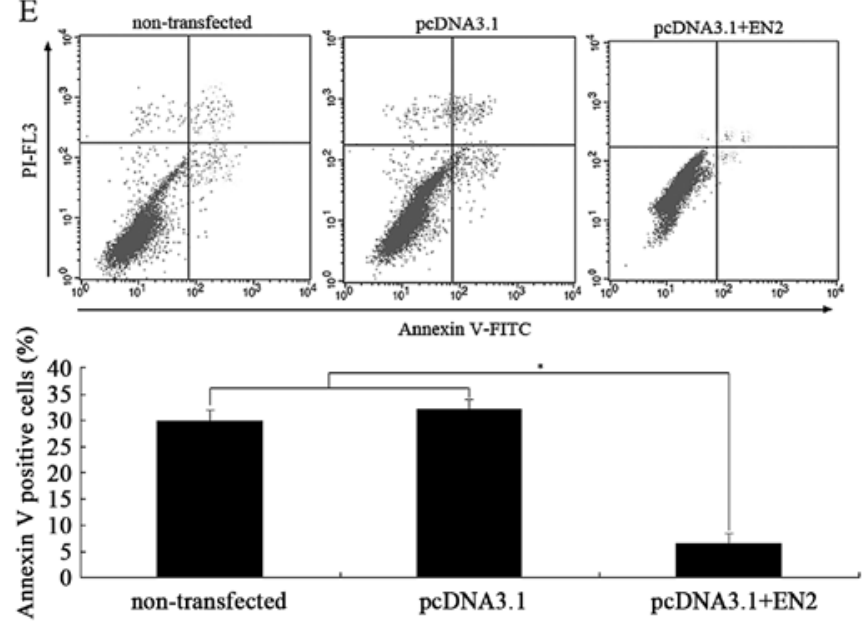

EN2-siRNA2 and EN2-siRNA3 was $>85 \%$ at 48 h by assessing the green fluorescent protein (GFP) expression under an inverted fluorescence microscope (data not shown). After EN2-siRNA1, EN2-siRNA2 and EN2-siRNA3 transduction for $48 \mathrm{~h}$ in EJ cells, the expression of EN2 mRNA was substantially reduced by $91.7,89.7$ and $81.0 \%$ while its protein expression was reduced by $85.4,74.7$ and $51.6 \%$, respectively, compared with the blank group (data not shown). Therefore, the EN2-siRNA1 plasmid was chosen for further study.

Selection of stable clones of siRNA-transfected EJ cells by $G 418$. The results showed that the positive proportion of GFP in the above three clones was $>85 \%$ while the intensity of red fluorescence in $\mathrm{C} 1$ and $\mathrm{C} 2$ cells was very weak, compared with $\mathrm{NC}$, which indicated that knockdown efficiency of $\mathrm{C} 1$ and C2 was very high (data not shown).

EN2 knockdown promotes cell cycle arrest and apoptosis of EJ cells but inhibits proliferation and invasion in vitro. After identifying the siRNA with the best inhibition for EN2 and two stable clones of EJ cells with EN2-siRNA transfection (C1 and C2), the effects of EN2 knockdown on the biological behavior of EJ cells were investigated. The results showed that 
A

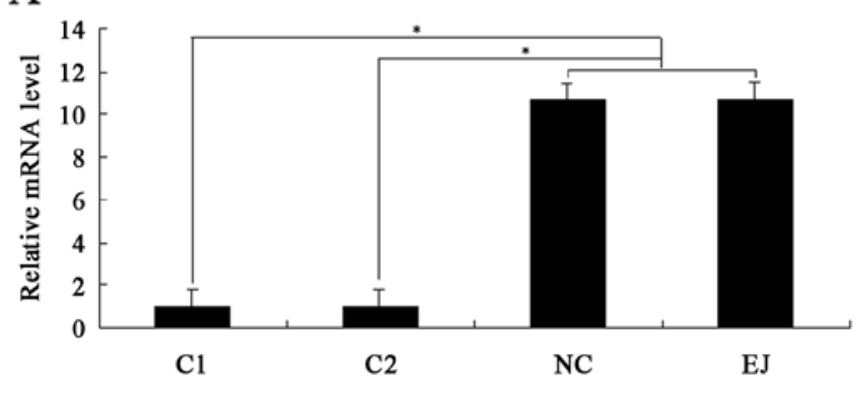

\section{B}

$\begin{array}{llll}\mathrm{C} 1 & \mathrm{C} 2 & \mathrm{NC} & \mathrm{EJ}\end{array}$
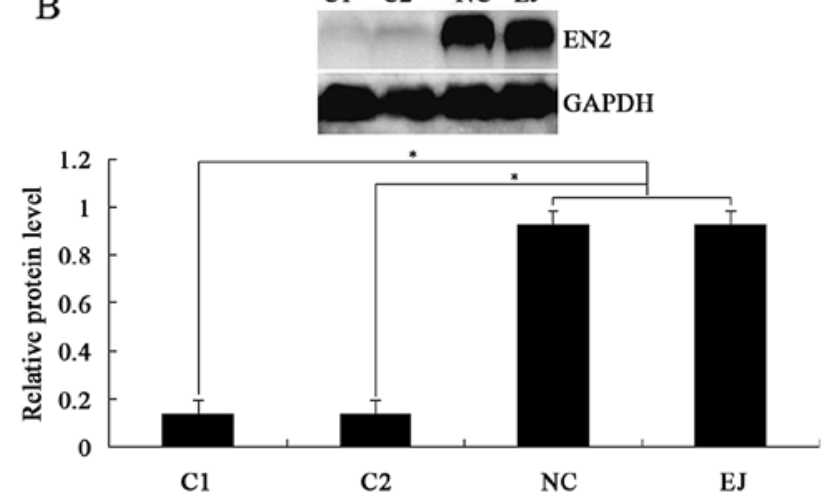
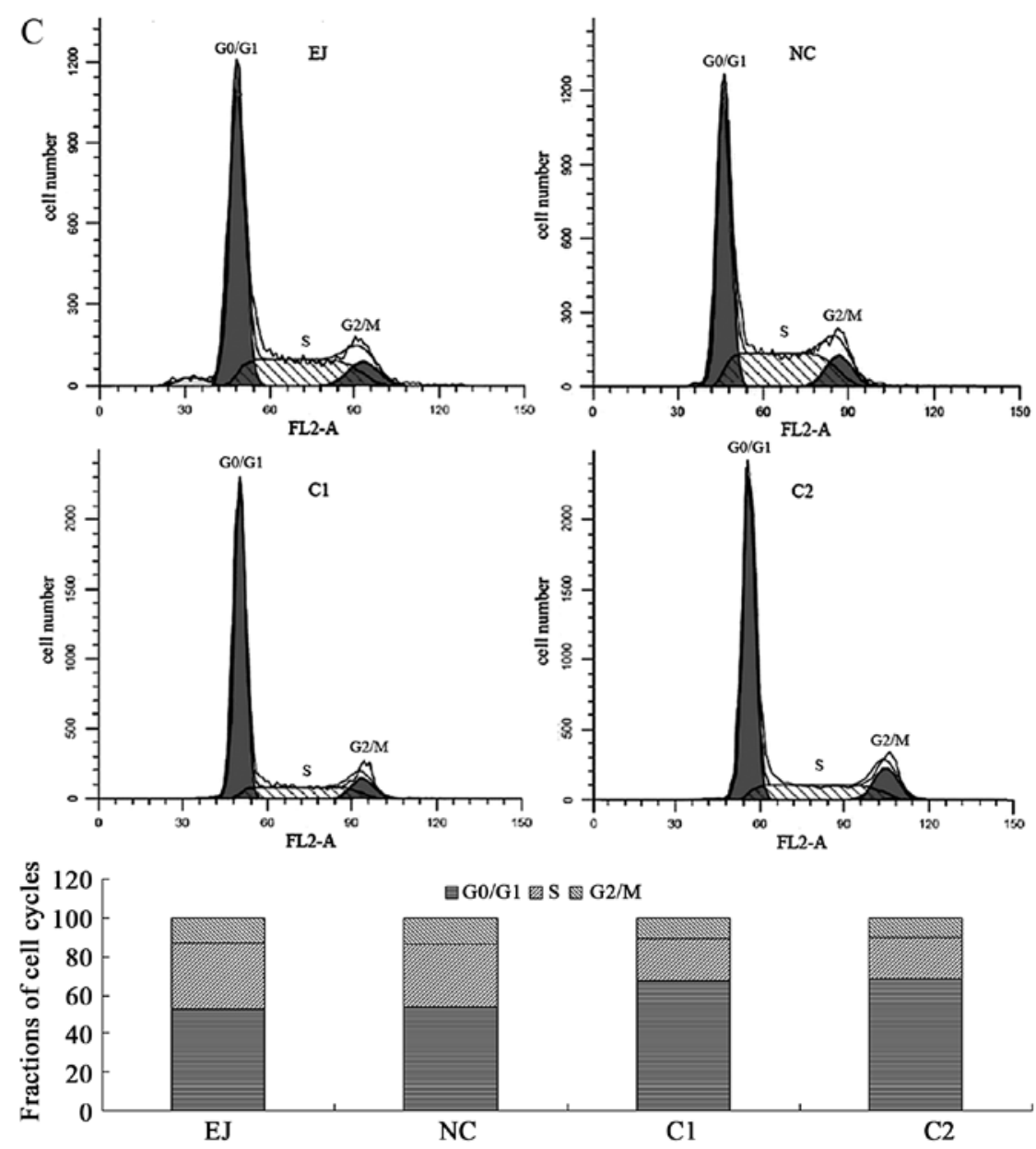

Figure 3. Effects of EN2 knockdown on the cell cycle, apoptosis, proliferation and invasion of BC cells in vitro. (A) Expression of EN2 mRNA was detected using qRT-PCR. (B) Expression of EN2 protein was detected by western blot analysis. (C) After cultivation for 48 h, analysis of cell cycle distribution of various cells, including EJ, $\mathrm{NC}, \mathrm{C} 1$ and $\mathrm{C} 2$, was performed by flow cytometry. The fractions of cells in the G0/G1, S and G2/M phases are shown in the representative histogram. ${ }^{*} \mathrm{P}<0.05$.

the expression levels of EN2 mRNA and protein in $\mathrm{C} 1$ and $\mathrm{C} 2$ were significantly downregulated than those in the $\mathrm{NC}$ and $\mathrm{EJ}$ cells (Fig. 3A and B). The percentages of cells in the $\mathrm{S}$ phase decreased from 35.2 to 21.7 and $21.5 \%$ in the $\mathrm{C} 1$ and $\mathrm{C} 2$ cells, respectively, whereas the percentages of cells in the $\mathrm{G} 0$ / G1 phase increased from $~ 52.1$ to 67.4 and $68.3 \%$ in $\mathrm{Cl}$ and $\mathrm{C} 2$, respectively. The percentages of cells in the $\mathrm{G} 2 / \mathrm{M}$ phase showed no significant differences among the various samples (Fig. 3C). These results suggest that EN2 downregulation leads to cell cycle arrest at the G0/G1 phase.
After cultivation for $48 \mathrm{~h}$, Annexin V/propidium iodide (PI) staining of various cells showed that the proportions of Annexin V-positive cells in $\mathrm{C} 1$ and $\mathrm{C} 2$ were $\sim 39.9$ and $\sim 38.7 \%$, respectively, whereas the proportion of Annexin V-positive cells in the EJ cells was only 9\% (Fig. 3D). These data suggest that EN2 downregulation promotes EJ cell apoptosis.

MTS assay demonstrated that EN2 knockdown significantly decreased the proliferation of EJ cells (Fig. 3E). Furthermore, EN2 knockdown also significantly decreased the invasive ability of the EJ cells (Fig. 3F). 

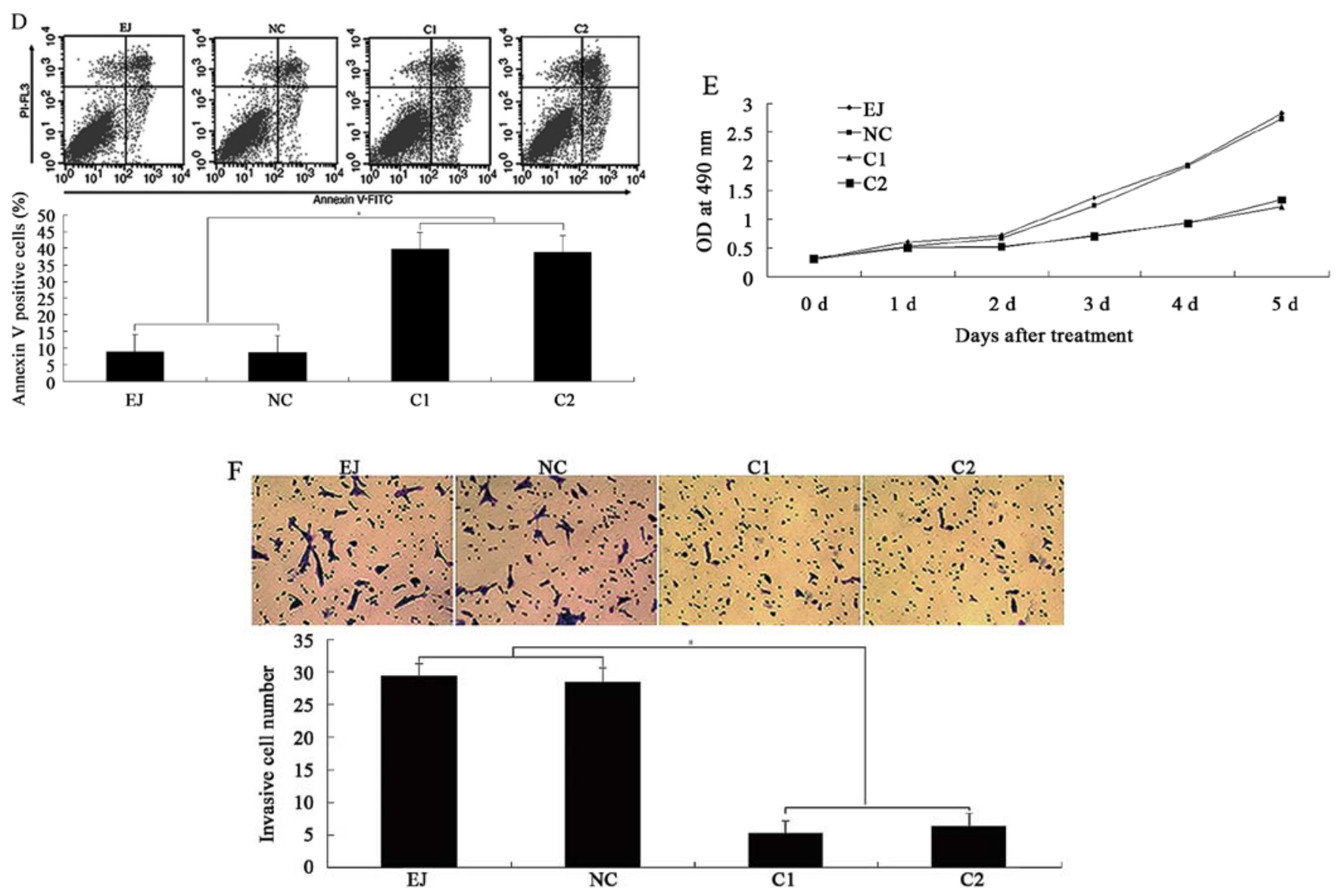

Figure 3. Continued. (D) After cultivation for $48 \mathrm{~h}$, the apoptosis of various cells was detected, and quantitative analysis of positive Annexin $\mathrm{V}$ cells in the different groups is shown in the representative histogram. (E) After obtaining stable clones, cell proliferation was assessed using the MTS assay. (F) Effects of EN2 knockdown on in vitro invasion. ${ }^{*} \mathrm{P}<0.05$.

Effects of EN2 knockdown on proliferation, apoptosis, invasion and metastasis of $B C$ in vivo. EJ and NC groups showed a significantly more rapid increase in tumor volume than that in the $\mathrm{C} 1$ and $\mathrm{C} 2$ groups $(\mathrm{P}<0.05)$. However, no differences were observed in regards to tumor size and growth pattern between the EJ and $\mathrm{NC}$ groups or between the $\mathrm{C} 1$ and $\mathrm{C} 2$ groups (Fig. 4A and B).

To further investigate the potential mechanisms of $\mathrm{BC}$ inhibition by EN2 knockdown, we detected the expression of various representative proteins that have been confirmed to be associated with the development and progression of tumors using western blot analysis. The results demonstrated that adhesion-related protein E-cadherin (CDH1), tumor-suppressor proteins, including TP53 and PTEN, as well as anti-apoptosis protein Bcl-2, were significantly downregulated in the EJ and NC groups. Matrix metalloproteinases, including MMP-2 and MMP-9, pro-apoptosis protein BAX, and cell cycle regulation protein cyclin D1, as well as tumor angiogenesis factors, including VEGF and PDGF, were also significantly downregulated in the $\mathrm{C} 1$ and $\mathrm{C} 2$ groups, which were consistent with the expression of their own genes (Fig. 4C and D).

Immunohistochemistry results showed that the protein expression levels of EN2 and Ki-67 were significantly lower in the $\mathrm{C} 1$ and $\mathrm{C} 2$ groups than those in the $\mathrm{EJ}$ and $\mathrm{NC}$ groups (Fig. 4E). The number of apoptotic cells was significantly increased in tumors from the $\mathrm{C} 1$ and $\mathrm{C} 2$ groups than the number in tumors from the EJ and NC groups as detected by TUNEL assay (Fig. 4E).

In addition, the number of micrometastatic events (observed under a microscope) in the lungs and livers was significantly lower in mice from the $\mathrm{C} 1$ and $\mathrm{C} 2$ groups than the events in lungs and livers from the EJ and NC groups (Fig. 4F and G). Similarly, the number of metastatic nodules (macroscopic) in the lungs and livers was apparently reduced in the $\mathrm{C} 1$ and $\mathrm{C} 2$ groups compared with that in the EJ and NC groups (Fig. $4 \mathrm{H}$; data not shown).

EN2 appears to induce activation of the phosphatidylinositol 3-kinase (PI3K) pathway by inhibiting PTEN. The PI3K pathway possesses a critical function in cell growth, proliferation and survival (25), and signaling via the P13K pathway is upregulated in many types of cancer $(26,27)$. Given the expression levels of EN2 and PTEN (the main inhibitor of PI3K-Akt pathway) in the aforementioned experiments, the levels of Akt phosphorylated at serine 473 (pAkt-473) and threonine 308 (pAkt-308), PI3K and PTEN protein were determined by western blot analysis in vitro. As shown in Fig. 5, the levels of pAkt-473, pAkt-308 and PI3K were significantly higher in the EJ and $\mathrm{NC}$ cell lines than those in the $\mathrm{C} 1$ cell line (EN2-siRNA-transfected). This result indicates that EN2 knockdown significantly decreased the levels of pAkt-473, pAkt-308 and PI3K, but increased PTEN expression. 

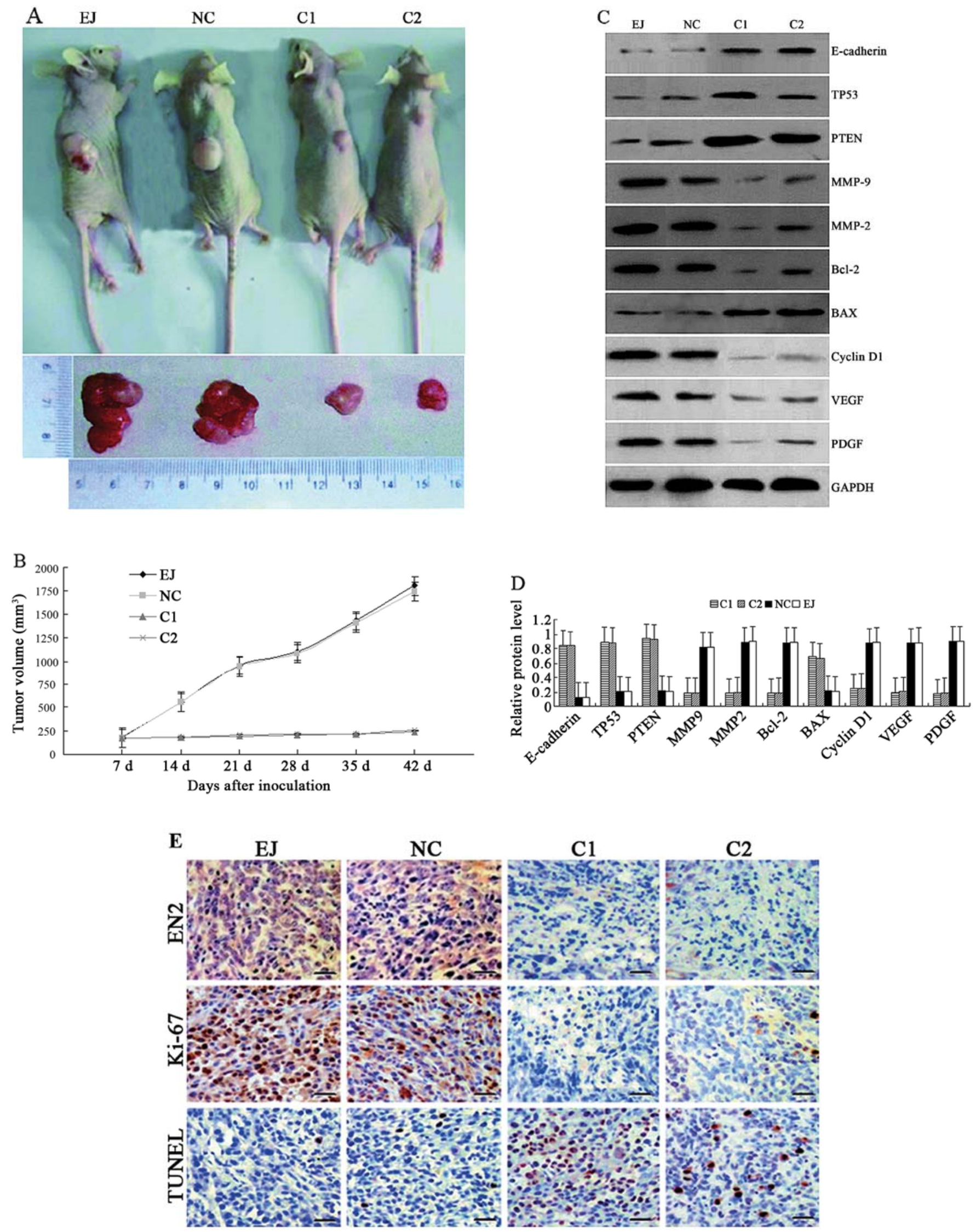

Figure 4. Inhibitory effects of EN2 knockdown on bladder cancer in vivo. (A) Images of representative mice and tumors are shown on day 42 after inoculation. (B) Tumor size was measured, and tumor volume was determined as described in Materials and methods every 7 days for 42 days, $\mathrm{n}=6$. (C and D) Adhesionrelated protein, tumor-suppressor protein, apoptosis-related protein, matrix metalloproteinases, cell cycle regulation protein and tumor angiogenesis factors were determined using western blot analysis. (E) Immunohistochemical detection of EN2, proliferation marker Ki-67 and apoptosis marker TUNEL. EN2positive staining was located in the tumor nuclei and cytoplasm, and more positive cells were observed in the EJ and $\mathrm{NC}$ groups than in the $\mathrm{C} 1$ and $\mathrm{C} 2 \mathrm{groups}$; $\mathrm{Ki}$-67-positive staining was located in the cell nuclei, and more positive cells were observed in the EJ and NC groups than in the $\mathrm{C} 1$ and $\mathrm{C} 2$ groups. In the TUNEL assay, positive cells were located in the cell nuclei. Scale bars, $50 \mu \mathrm{m}$. 

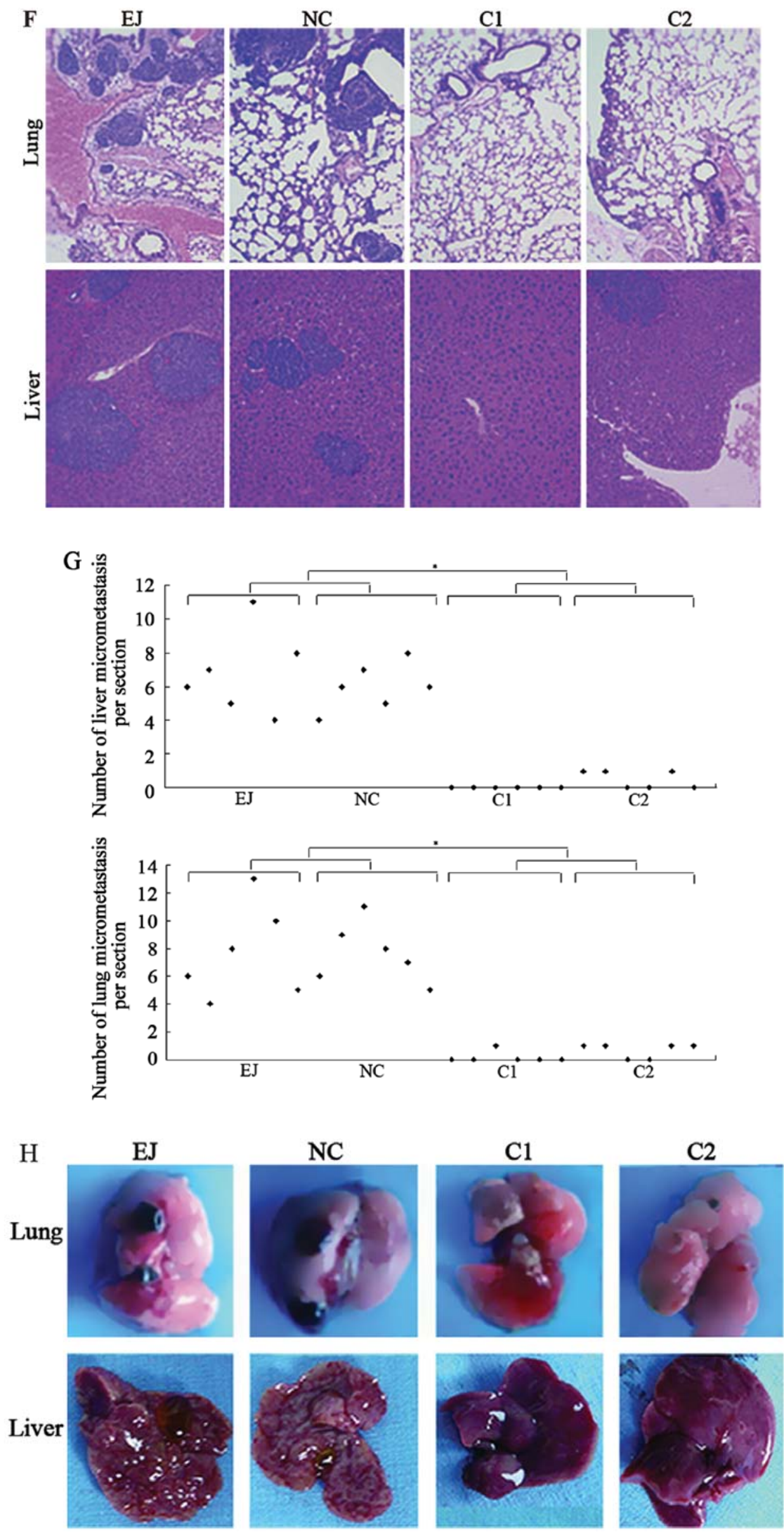

Figure 4. Continued. (F) Representative images of hematoxylin and eosin-stained sections of lung and liver micrometastases, and (G) quantification of the liver and lung micrometastases. (H) Representative images of lung and liver metastases in nude mice. Scale bars, $100 \mu \mathrm{m} .{ }^{*} \mathrm{P}<0.05$. 


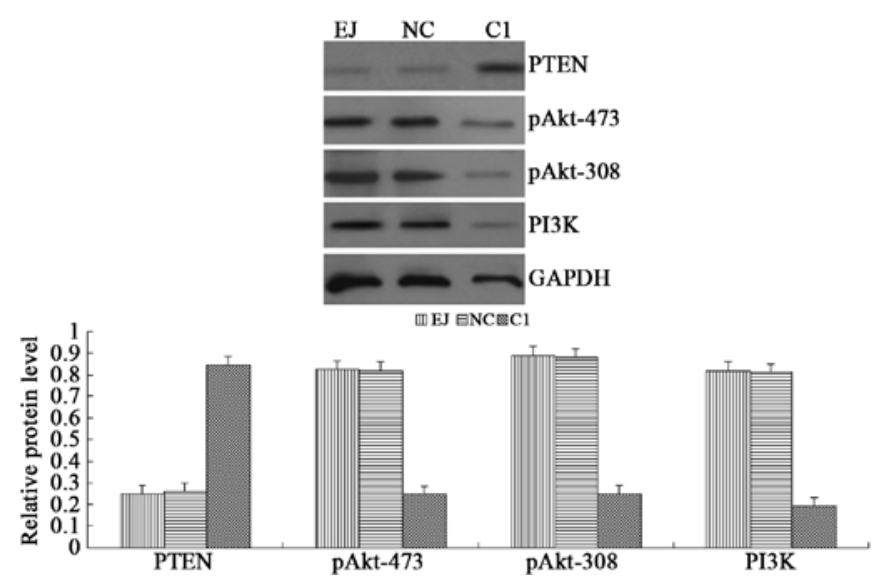

Figure 5. EN2 appears to induce PI3K pathway activation by inhibiting PTEN. The protein levels of PTEN, pAkt-473, pAkt-308 and PI3K were detected by western blot analysis in the EJ cells with different treatments.

\section{Discussion}

EN2, a homeobox-containing transcription factor, was identified as a candidate oncogene in breast and prostate cancer. Previous studies indicate that EN2 is overexpressed in human breast and prostate cancer cells, and downregulation of EN2 expression causes a decrease in breast and prostate cancer cell proliferation $(18,19)$. In the present study, EN2 was highly expressed in BC cell lines. The ectopic expression of EN2 in normal urothelial cells significantly enhanced cellular proliferation and invasion, but inhibited cellular apoptosis. Moreover, RNAi-mediated EN2 silencing significantly downregulated the protein levels of EN2 in vitro and in vivo. More importantly, EN2 knockdown significantly promoted cell cycle arrest and apoptosis of tumor cells and inhibited tumor growth and distant metastasis. All of these findings suggest that EN2 has potential functions in $\mathrm{BC}$ development and progression and is a promising gene-targeting therapy for $\mathrm{BC}$.

The cell cycle has important functions in cell proliferation, differentiation and tumor progression and is regulated by intracellular and extracellular signal transduction pathways (28). In the present study, the number of cells in the G0/G1 phase was significantly increased, whereas that in the $\mathrm{S}$ phase was significantly decreased in the $\mathrm{C} 1$ and $\mathrm{C} 2$ cells. This result suggests that EN2 knockdown induced G0/G1 phase arrest and apoptosis, as well as inhibited tumor cell proliferation. Furthermore, the cell proliferation assay indicated that EN2 knockdown led to a significant decrease in BC cell proliferation. After constructing the xenograft tumor models in nude mice, the tumor volumes in the $\mathrm{C} 1$ and $\mathrm{C} 2$ groups were significantly lower than those in the EJ and NC groups on day 42. Furthermore, cell apoptosis was detected using TUNEL assay, and the Ki-67 protein expression was determined by immunohistochemistry in vivo. The results showed that the number of apoptotic cells was significantly increased and Ki-67 protein expression was significantly decreased in tumors in the $\mathrm{C} 1$ and $\mathrm{C} 2$ groups compared with those in the EJ and NC groups. These data indicate that RNAi-mediated EN2 gene silencing inhibited tumor growth and induced apoptosis of BC cells both in vitro and in vivo.
To further investigate the potential molecular mechanisms of the effects of EN2 knockdown on tumor growth inhibition, we detected the expression levels of various common proteins that are related to the development and progression of tumors in vivo. The results indicated that protumor proteins were downregulated, whereas antitumor proteins were upregulated after EN2 knockdown. Numerous genes and proteins are involved in the development and progression of tumors, including BC. Loss of TP53 and PTEN tumor suppressors is common in BC (29,30). The Bcl-2 family functions as a 'life/ death switch' that integrates diverse intercellular and intracellular cues to determine whether the stress apoptosis pathway should be activated (31). The p53 gene precisely regulates cell apoptosis via activating apoptosis promoters of the Bcl-2 family, such as BAX, or inhibiting antiapoptosis molecules, such as Bcl-2 (32). PTEN can negatively regulate the PI3K/ Akt pathway, which regulates several relevant processes for tumor growth and progression, such as cell survival, motility, invasion, cell cycle progression and angiogenesis $(33,34)$. Genetic aberrations in the regulatory circuits that govern transit through the G1 phase of the cell cycle occur frequently in human cancer, and overexpression of cyclin D1 is one of the most commonly observed alterations, including BC $(35,36)$. Studies indicate that cyclin D1 downregulation contributes to inhibition of $\mathrm{BC}$ proliferation by inducing cell cycle $\mathrm{G} 0$ / G1 arrest (37,38). VEGF and PDGF have important functions in tumor angiogenesis for neoangiogenesis, which further promotes tumor growth (39). CDH1 (E-cadherin) is a calciumdependent cell adhesion molecule that inhibits tumor invasion and metastasis through stabilization of cell-cell adhesion (40). MMP-2 and MMP-9 can degrade epithelial-mesenchymal transition (ECM) and promote tumor metastasis (41).

The PI3K/AKT signaling pathway is a frequently dysregulated pathway in cancer $(42,43)$ and possesses a major function in bladder carcinogenesis (44-48). PTEN is the antagonist of PI3K, which removes the 3' phosphate of PIP3 and attenuates downstream signaling of activated PI3K (49). Therefore, we further investigated the effects of EN2 knockdown on the PI3K/Akt pathway in vitro. EN2 knockdown significantly decreased the levels of pAkt-473, pAkt-308 and PI3K protein, but increased PTEN protein. This finding suggests that EN2 may activate the PI3K/Akt pathway by inhibiting PTEN, thereby promoting the progression of $\mathrm{BC}$.

In addition to transcription, EN2 protein may have a regulatory function in translation as it can bind directly to the eukaryotic translation initiation factor 4E (eIF4E) with high affinity and specificity (50). EN2 should have the same characteristics as other homeoproteins since it is a homeoboxcontaining transcription factor. Zhou et al (51) indicated that $\mathrm{Nkx3}$.1, a homeoprotein transcription factor, functions within the cells that produce them in a cell autonomous manner as well as can regulate genes and inhibit cell proliferation in a non-cell autonomous manner. Prin et al (52) reported that Hox 4 proteins regulate Eph/ephrins and other cell-surface proteins during chick and mouse embryo development. These proteins can also function in a non-cell-autonomous manner to induce apical cell enlargement on both sides of their expression border. Therefore, we hypothesized that EN2 may induce pro-oncogenes, such as VEGF, or inhibit anti-oncogenes, such as PTEN, to promote the development and progression of $\mathrm{BC}$ 
via the aforementioned three mechanisms (i.e., regulating translation by binding directly to eIF4E and functioning in a cell autonomous and non-cell-autonomous manner). This hypothesis needs to be further verified.

Notably, we found that most mice in the EJ and NC groups presented with liver and lung metastases, whereas mice in the $\mathrm{C} 1$ and $\mathrm{C} 2$ groups did not show liver and lung metastases. This result suggests that EN2 knockdown significantly inhibited the metastasis of BC cells to the liver and lung in vivo.

The effects of EN2 knockdown on gene expression profiling of BC were not analyzed due to the limitation in experimental conditions, which may further confirm the results in the present study. However, the study indicated that EN2 may promote cell proliferation, invasion, and metastasis in BC by activating the PI3K/Akt pathway and inhibiting PTEN. Importantly, EN2 knockdown significantly decreased tumor growth of BC through regulating the cell cycle, apoptosis and ECM-related proteins. Thus, EN2 may be a candidate oncogene in BC and may be used as a therapeutic target for the treatment of BC.

\section{Acknowledgements}

The present study was supported by the Major Research Fund for the People's Livelihood of Guangzhou Science and Technology Plan (2011Y-00003).

\section{References}

1. Jemal A, Siegel R, Xu J and Ward E: Cancer statistics, 2010. CA Cancer J Clin 60: 277-300, 2010.

2. Han S, Zhang S, Chen W and Li C: Analysis of the status and trends of bladder cancer incidence in China. Oncol Prog 11: 89-95, 2013 (In Chinese).

3. Babjuk M, Burger M, Zigeuner R, Shariat SF, van Rhijn BW, Compérat E, Sylvester RJ, Kaasinen E, Böhle A, Palou Redorta J, et al: EAU guidelines on non-muscle-invasive urothelial carcinoma of the bladder: update 2013. Eur Urol 64: 639-653, 2013.

4. Gakis G, Witjes JA, Compérat E, Cowan NC, De Santis M, Lebret T, Ribal MJ and Sherif AM; European Association of Urology: EAU guidelines on primary urethral carcinoma. Eur Urol 64: 823-830, 2013.

5. Na Y and Guo Z: Practice of Urology. People's Medical Press, Beijing, pp280-296, 2009 (In Chinese).

6. Wu X: Urothelial tumorigenesis: a tale of divergent pathways. Nat Rev Cancer 5: 713-725, 2005.

7. Efstathiou JA, Spiegel DY, Shipley WU, Heney NM, Kaufman DS, Niemierko A, Coen JJ, Skowronski RY, Paly JJ, McGovern FJ, et al: Long-term outcomes of selective bladder preservation by combined-modality therapy for invasive bladder cancer: the MGH experience. Eur Urol 61: 705-711, 2012.

8. Wedeen CJ and Weisblat DA: Segmental expression of an engrailed-class gene during early development and neurogenesis in an annelid. Development 113: 805-814, 1991.

9. Wanninger A and Haszprunar G: The expression of an engrailed protein during embryonic shell formation of the tusk-shell, Antalis entails (Mollusca, Scaphopoda). Evol Dev 3: 312-231, 2001.

10. Fjose A, McGinnis WJ and Gehring WJ: Isolation of a homoeo box-containing gene from the engrailed region of Drosophila and the spatial distribution of its transcripts. Nature 313: 284-289, 1985.

11. Holland LZ, Kene M, Williams NA and Holland ND: Sequence and embryonic expression of the amphioxus engrailed gene (AmphiEn): the metameric pattern of transcription resembles that of its segment-polarity homolog in Drosophila. Development 124: 1723-1732, 1997.

12. Joyner AL, Kornberg T, Coleman KG, Cox DR and Martin GR: Expression during embryogenesis of a mouse gene with sequence homology to the Drosophila engrailed gene. Cell 43: 29-37, 1985.

13. Hanks M, Wurst W, Anson-Cartwright L, Auerbach AB and Joyner AL: Rescue of the En-1 mutant phenotype by replacement of En-1 with En-2. Science 269: 679-682, 1995.
14. Hanks MC, Loomis CA, Harris E, Tong CX, Anson-Cartwright L, Auerbach A and Joyner A: Drosophila engrailed can substitute for mouse Engrailed1 function in mid-hindbrain, but not limb development. Development 125: 4521-4530, 1998.

15. Simon HH, Saueressig H, Wurst W, Goulding MD and O'Leary DD: Fate of midbrain dopaminergic neurons controlled by the engrailed genes. J Neurosci 21: 3126-3134, 2001.

16. Alberi L, Sgado P and Simon HH: Engrailed genes are cell autonomously required to prevent apoptosis in mesencephalic dopaminergic neurons. Development 131: 3229-3236, 2004.

17. Degenhardt K, Rentschler S, Fishman G and Sassoon DA: Cellular and cis-regulation of En-2 expression in the mandibular arch. Mech Dev 111: 125-136, 2002.

18. Martin NL, Saba-El-Leil MK, Sadekova S, Meloche S and Sauvageau G: EN2 is a candidate oncogene in human breast cancer. Oncogene 24: 6890-6901, 2005.

19. Bose, SK, Bullard RS and Donald CD: Oncogenic role of engrailed-2 (en-2) in prostate cancer cell growth and survival. Transl Oncogenomics 3: 37-43, 2008.

20. Morgan R, Boxall A, Bhatt A, et al: Engrailed-2 (EN2): a tumor specific urinary biomarker for the early diagnosis of prostate cancer. Clin Cancer Res 17: 1090-1098, 2011.

21. Pandha H, Sorensen KD, Orntoft TF, Langley S, Hoyer S, Borre M and Morgan R: Urinary engrailed-2 (EN2) levels predict tumour volume in men undergoing radical prostatectomy for prostate cancer. BJU Int 110: E287-E292, 2012.

22. McGrath SE, Michael A, Pandha H and Morgan R: Engrailed homeobox transcription factors as potential markers and targets in cancer. FEBS Lett 587: 549-554, 2013.

23. Morgan R, Bryan RT, Javed S, Launchbury F, Zeegers MP, Cheng KK, James ND, Wallace DM, Hurst CD, Ward DG, et al: Expression of Engrailed-2 (EN2) protein in bladder cancer and its potential utility as a urinary diagnostic biomarker. Eur J Cancer 49: 2214-2222, 2013.

24. Livak KJ and Schmittgen TD: Analysis of relative gene expression data using real-time quantitative PCR and the 2 (-Delta Delta C(T)) method. Methods 25: 402-408, 2001.

25. Cantley LC: The phosphoinositide 3-kinase pathway. Science 296: 1655-1657, 2002.

26. Luo J, Manning BD and Cantley LC: Targeting the PI3K-Akt pathway in human cancer: rationale and premise. Cancer Cell 4: 257-262, 2003.

27. Shaw RJ and Cantley LC: Ras, PI(3)K and mTOR signalling controls tumour cell growth. Nature 441: 424-430, 2006.

28. Peter M and Herskowitz I: Joining the complex: cyclin-dependent kinase inhibitory proteins and the cell cycle. Cell 79: 181-184, 1994.

29. Al Hussain TO and Akhtar M: Molecular basis of urinary bladder cancer. Adv Anat Pathol 20: 53-60, 2013.

30. Cordes I, Kluth M, Zygis D, Rink M, Chun F, Eichelberg C, Dahlem R, Fisch M, Höppner W, Wagner W, et al: PTEN deletions are related to disease progression and unfavourable prognosis in early bladder cancer. Histopathology 63: 670-677, 2013.

31. Adams JM and Cory S: The Bcl-2 apoptotic switch in cancer development and therapy. Oncogene 26: 1324-1337, 2007.

32. Haupt S, Berger M, Goldberg Z and Haupt Y: Apoptosis - the $\mathrm{p} 53$ network. J Cell Sci 116: 4077-4085, 2003.

33. Maehama T and Dixon JE: The tumor suppressor, PTEN/MMAC1, dephosphorylates the lipid second messenger, phosphatidylinositol 3,4,5-trisphosphate. J Biol Chem 273: 13375-13378, 1998.

34. Nicholson KM and Anderson NG: The protein kinase B/Akt signaling pathway in human malignancy. Cell Signal 14: 381-395, 2002.

35. Diehl JA: Cycling to cancer with cyclin D1. Cancer Biol Ther 1: 226-231, 2002.

36. Kopparapu PK, Boorjian SA, Robinson BD, Downes M, Gudas LJ, Mongan NP and Persson JL: Expression of cyclin d1 and its association with disease characteristics in bladder cancer. Anticancer Res 33: 5235-5242, 2013.

37. Fang Y, Cao Z, Hou Q, Ma C, Yao C, Li J, Wu XR and Huang C: Cyclin d1 downregulation contributes to anticancer effect of isorhapontigenin on human bladder cancer cells. Mol Cancer Ther 12: 1492-1503, 2013.

38. Gee JR, Burmeister CB, Havighurst TC and Kim K: Cyclinmediated G1 arrest by celecoxib differs in low-versus high-grade bladder cancer. Anticancer Res 29: 3769-3775, 2009.

39. Appelmann L, Liersch R, Kessler T, Mesters RM and Berdel WE: Angiogenesis inhibition in cancer therapy: platelet-derived growth factor (PDGF) and vascular endothelial growth factor (VEGF) and their receptors: biological functions and role in malignancy. Recent Results Cancer Res 180: 51-81, 2010. 
40. Moh MC and Shen S: The roles of cell adhesion molecules in tumor suppression and cell migration: a new paradox. Cell Adh Migr 3: 334-336, 2009.

41. Rodriguez Faba O, Palou-Redorta J, Fernández-Gómez JM, Algaba F, Eiró N, Villavicencio H and Vizoso FJ: Matrix metalloproteinases and bladder cancer: what is new? ISRN Urol 2012. 581539, 2012.

42. Yuan TL and Cantley LC: PI3K pathway alterations in cancer: variations on a theme. Oncogene 27: 5497-5510, 2008.

43. Courtney KD, Corcoran RB and Engelman JA: The PI3K pathway as drug target in human cancer. J Clin Oncol 28: 1075-1083, 2010.

44. López-Knowles E, Hernández S, Malats N, Kogevinas M Lloreta J, Carrato A, Tardón A, Serra C and Real FX: PIK3CA mutations are an early genetic alteration associated with FGFR3 mutations in superficial papillary bladder tumors. Cancer Res 66 7401-7404, 2006.

45. Platt FM, Hurst CD, Taylor CF, Gregory WM, Harnden $P$ and Knowles MA: Spectrum of phosphatidylinositol 3-kinase pathway gene alterations in bladder cancer. Clin Cancer Res 15: 6008-6017, 2009.

46. Knowles MA, Platt FM, Ross RL and Hurst CD: Phosphatidylinositol 3-kinase (PI3K) pathway activation in bladder cancer. Cancer Metastasis Rev 28: 305-316, 2009.
47. Askham JM, Platt F, Chambers PA, Snowden H, Taylor CF and Knowles MA: AKT1 mutations in bladder cancer: identification of a novel oncogenic mutation that can co-operate with E17K. Oncogene 29: 150-155, 2010.

48. Calderaro J, Rebouissou S, de Koning L, Masmoudi A, Hérault A, Dubois T, Maille P, Soyeux P, Sibony M and de la Taille A: PI3K/AKT pathway activation in bladder carcinogenesis. Int J Cancer 134: 1776-1784, 2014

49. Cully M, You H, Levine AJ and Mak TW: Beyond PTEN mutations: the PI3K pathway as an integrator of multiple inputs during tumorigenesis. Nat Rev Cancer 6: 184-192, 2006.

50. Nedelec S, Foucher I, Brunet I, Bouillot C, Prochiantz A and Trembleau A: Emx2 homeodomain transcription factor interacts with eukaryotic translation initiation factor $4 \mathrm{E}$ (eIF4E) in the axons of olfactory sensory neurons. Proc Natl Acad Sci USA 101: 10815-10820, 2004.

51. Zhou J, Qin L, Tien JC, Gao L, Chen X, Wang F, Hsieh JT and $\mathrm{Xu} \mathrm{J}$ : Nkx3.1 functions as para-transcription factor to regulate gene expression and cell proliferation in non-cell autonomous manner. J Biol Chem 287: 17248-17256, 2012.

52. Prin F, Serpente P, Itasaki N and Gould AP: Hox proteins drive cell segregation and non-autonomous apical remodelling during hindbrain segmentation. Development 141: 1492-1502, 2014. 